\title{
Comment: Novel voltage/current-mode quadrature oscillator using current differencing transconductance amplifier
}

\author{
Amit Kumar
}

Received: 23 June 2010/Revised: 28 June 2010/ Accepted: 30 June 2010/Published online: 17 July 2010

(C) Springer Science+Business Media, LLC 2010

This comment relates to the paper [1] published recently in this journal. The main proposition of this paper is CDTAbased voltage/current controlled quadrature oscillator presented in Fig. 2 of [1] and reproduced here in Fig. A. It should be noticed that the paper [1] was submitted on 27 September 2008, was revised on 24 January 2009 and subsequently accepted on 17 February 2009 (published on line: 12 March 2009).

The same author also published yet another paper [2] proposing two CDTA based quadrature oscillator see Fig. 2(a) of [2]. The purpose of this note is to point out that the circuit recently published in [1] as reproduced here as Fig. A is exactly same as Fig. 2(a) of [2] which was published on 10 February 2009 but already accepted on

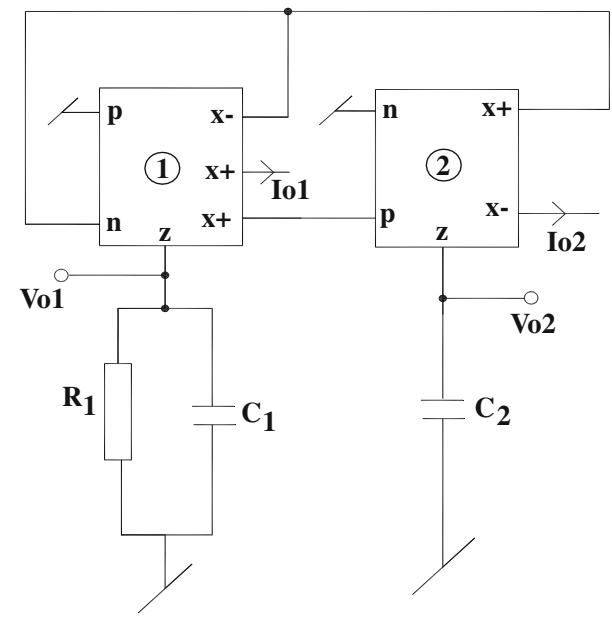

Fig. A

A. Kumar $(\bowtie)$

IPEC Engineering College, Shahibabad, Ghaziabad, UP, India

e-mail: ak16.kumar@gmail.com
19 December 2008. Thus, it is clear that the author proceeded with duplicating the same circuit in the paper [1] eventhough he had the opportunity to not do so when the paper [1] being revised in January 2009.

In conclusion, the circuit reported in Fig. 2 of [1] is an exact duplication of circuit in Fig. 2(a) of [2] by the same author. This duplication could have easily been avoided since paper [1] was revised in January 2009 after paper [2] had already been accepted in December 2008.

It was thought necessary to bring this to the attention of the Journal and its readership so that this esteemed journal continues to maintain its name and fame.

\section{References}

1. Lahiri, A. (2009). Novel voltage/current-mode quadrature oscillator using current differencing transconductance amplifier. Analog Integrated Circuits and Signal Processing, 61(2), 199-203.

2. Lahiri, A. (2009). New current-mode quadrature oscillators using CDTA. IEICE Electronics Express, 6(3), 135-140.

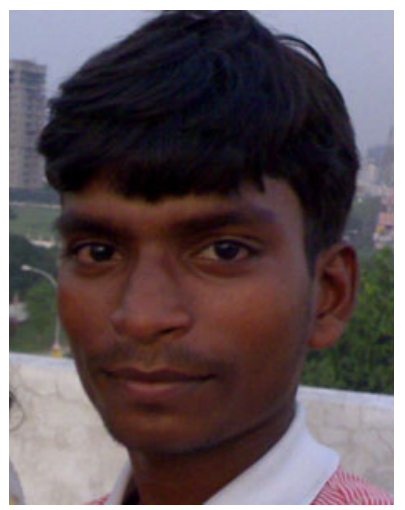

Amit Kumar was born on November 16, 1985 in Gorakhpur, Uttar Pradesh, India. He obtained his B.Tech. degree from Kamla Nehru Institute of Technology (KNIT), Sultanpur (Uttar Pradesh), India. Amit kumar joined as a Lecturer in the Department of Electronics and Communication Engineering in 2008 at Inderprastha Engineering College (IPEC), Shahibabad, Ghaziabad, Uttar Pradesh, India. His research interest is in the area of Analog Integrated Circuits. 